\title{
A systematic review and meta-analysis of epidemiology of depression in people living with HIV in east Africa
}

\author{
Getinet Ayano ${ }^{1 *}$, Melat Solomon ${ }^{1}$ and Mebratu Abraha²
}

\begin{abstract}
Background: Depression is the most prevalent psychiatric disorder among people living with HIV (PLWHIV) and is associated with poor quality of life, additional comorbidities, disability, unemployment, poorer therapeutic outcomes and risky behaviors. The present systematic review and meta-analysis aims to systematically summarize empirical evidence and to formulate recommendations for future research.

Methods: We searched PubMed, EMBASE, SCOPUS, and relevant literature for possible studies to include. A qualitative and quantitative analysis was undertaken for this systematic review. Subgroup and sensitivity analysis were performed. Cochran's Q- and the $\mathrm{I}^{2}$ test were used to assess heterogeneity. The presence of publication bias was evaluated by using Egger's test and visual inspection of the symmetry in funnel plots.

Results: Of 283 titles initially identified, 81 abstracts were eligible for review. Of these, 46 articles qualified for full text review and 19 were retained. In our meta-analysis the pooled prevalence of depression in PLWHIV was 38\% (95\% Cl 29.30-47.54). The pooled prevalence estimates of depression was $49.79 \%$ in Ethiopia and 30.88\% in Uganda. In addition, the prevalence of depression was $12.40 \%$ and $46 \%$ as measured by diagnostic and screening instrument respectively. Our qualitative synthesis showed that factors such as having opportunistic infection, perceived stigma, negative life event, WHO clinical staging of disease, hospitalization in the past one month, stressful life events, food insecurity, self-efficacy, missed frequency of clinic visit, frequency of follow-up, older age, low income, urban residence and being government employee were strongly and significantly associated with depression in PLWHIV in east Africa.

Conclusion: The pooled prevalence estimates of prevalence of depression in PLWHIV was 38\%. The prevalence estimates of depression in PLWHIV in Ethiopia was significantly higher than Uganda. In addition the prevalence of depression was significantly higher in studies conducted by screening than diagnostic instrument. Routine screening and integrated management of depression into the existing HIV care services is warranted. Validation and use of standard instrument to assess depression in PLWHIV is needed. Moreover, longitudinal and community based studies focusing on incidence and determinates of depression in PLWHIV are recommended.
\end{abstract}

Keywords: Prevalence, HIV, AIDS, Determinants, Factors, Depression, Systematic review, Meta-analysis, East Africa

\footnotetext{
* Correspondence: babiget2015@gmail.com

${ }^{1}$ Research and Training Department, Amanuel Mental Specialized Hospital,

Addis Ababa, Ethiopia

Full list of author information is available at the end of the article
}

(c) The Author(s). 2018 Open Access This article is distributed under the terms of the Creative Commons Attribution 4.0 International License (http://creativecommons.org/licenses/by/4.0/), which permits unrestricted use, distribution, and reproduction in any medium, provided you give appropriate credit to the original author(s) and the source, provide a link to the Creative Commons license, and indicate if changes were made. The Creative Commons Public Domain Dedication waiver (http://creativecommons.org/publicdomain/zero/1.0/) applies to the data made available in this article, unless otherwise stated. 


\section{Background}

Depression is the most prevalent psychiatric disorder among people living with HIV (PLWHIV) and is associated with poorer therapeutic outcomes and risky behaviors. Different epidemiological studies have estimated the prevalence of depression in PLWHIVto be between $2.27 \%$ and $76.7 \%$ [1-20]. In fact, it is one of the leading causes of morbidity and mortality among PLWHIV [21].

In the past decades, studies have determined the prevalence of depression in PLWHIV. However, the overall prevalence rate of depression in PLWHIV remains unclear in east Africa; previous studies reported prevalence rates between $2.7 \%$ and $76.7 \%$ [1-20]. Several factors may contribute to this wide range of prevalence rates, including: (i) differences between included PLWHIV with respect to the stages of HIV disease, treatment status and CD4 level (ii) the use of different instruments to assess depression with different psychometric properties; and (iii) the use of different criteria to define depression [22].

Depression is the most commonly experienced psychological conditions experienced by PLWHIV and is associated with poor quality of life [23], additional comorbidities [24], disability, and unemployment [25-27]. In addition, depression in PLWHV leads poor social conditions, poor treatment adherence and, poor therapeutic outcomes, and risky behaviors [28-31].

A number of factors can predispose PLWHIV to depression including, having opportunistic infection $[9,10]$, perceived stigma [2], negative life event [26], having severe WHO clinical stage diseases $[2,9,10]$, stressful life events [26], food insecurity [9], older age [17], low income [3] and advanced HIV disease [22].

Evidence shows that east Africa is the region most affected by HIV in the world next to south Africa [32]. However, the there are no systematic review and meta-analysis studies conducted on the epidemiology of depression in PLWHIV in east Africa. Therefore, the main objective of this systematic review and meta-analysis is to summarize the available empirical evidence in east Africa on: [1] the prevalence of depression in people living with HIV (PLWHIV) and [2] the determinants of depressionin PLWHIV and to formulate recommendations for future clinical practice and research.

\section{Methods/design}

We conducted extensive search of literature as indicated in the guideline of reporting systematic review and meta-analysis (PRISMA) [32]. Three databases such as PubMed, Embase, and Scopus were consulted for our literature search. We conducted our search in Pubmed using the following terms and keywords: "Epidemiology OR prevalence OR magnitude OR incidence AND depression OR depressive symptoms OR depressive disorder OR depressive AND HIV OR human immunodeficiency virus
OR AIDS AND factor OR risk OR risk factor OR determinant AND Ethiopia OR Eritrea OR Kenya OR Uganda OR Tanzania OR Sudan OR Djibouti OR Somalia OR Rwanda OR east Africa". For the other two databases (Embase and Scopus) we employed specific-subjects headings as advised for each databases. In addition, in order to identify other relevant articles we manually searched the reference lists of eligible articles.

\section{Eligibility criteria}

Two reviewers (GA and MA) evaluated the relevant articles using their title and abstracts prior to retrieval of full-text articles. The retrieved full-text articles were further screened according to pre-specified inclusion and exclusion criteria. We resolved disagreements by discussing with a third reviewer (MS).

\section{Inclusion criteria}

- Design type -Cross sectional and other observational studies

- Study subject- people living with HIV

- Articles published in English language

- Studies which reported magnitude of depression in PLWHIV

- Articles that assessed risk factors of depression in PLWHIV

- Studies done in east Africa

\section{Exclusion criteria}

- We excluded commentaries, editorials, letters, reviews, and interventional studies

- Duplicate studies were also excluded

\section{Methods for data extraction and quality assessment}

We used standardized data extraction form to extract data from identified studies. The following information were extracted for each included study: The name of the first author, publication date, study design, associated factors, sample size study setting, tools used for assessing outcome, confounders adjusted for, risk estimate (OR) and their $95 \%$ confidence interval. Data extraction from source documents was done independently by two investigators. Disagreements were resolved by consensus.

The quality of included studies was evaluated by using a modified version of the Newcastle-Ottawa Scale (NOS) [33]. Sample representativeness and size, comparability between participants, ascertainment of depressive symptoms, and statistical quality were the domains NOS scale uses to assess the quality of each studies. Actual agreement and agreement beyond chance (unweighted Kappa) were used to evaluate the agreement between the two reviewers. We considered the values 0 as poor agreement, 
$0.01-0.20$ as slight agreement, $0.21-0.40$ as fair agreement, $0.41-0.60=$ moderate agreement, $0.61-0.80$ as substantial agreement, and $0.81-1.00$ as almost perfect agreement [34].

\section{Data synthesis and analysis}

Comprehensive meta-analysis software version3 was used for meta-analysis and forest plots that showed combined estimates with $95 \% \mathrm{CI}$. The overall pooled prevalence was estimated by random effect meta-analysis [35]. Heterogeneity was evaluated using $Q$ statistic and the $\mathrm{I}^{2}$ statistics [35]. The magnitude of statistical heterogeneity between studies was assessed using $I^{2}$ statistic and values of 25, 50 and $75 \%$ were considered to represent low, medium and high, respectively [36]. For the data identified as heterogeneous, a random-effects model was used during analysis. When statistical pooling is not possible, non-pooled data was presented in table form. Meta-regression was performed to explore the potential source of heterogeneity.

The instrument used to assess depression and the country where the studies were conducted were used to determine the possible source of heterogeneity between the studies. In addition, we carried out a leave-one-out sensitivity analysis to evaluate the key studies that exert major impact on between-study heterogeneity. Publication bias was assessed by funnel plot and Egger's regression tests

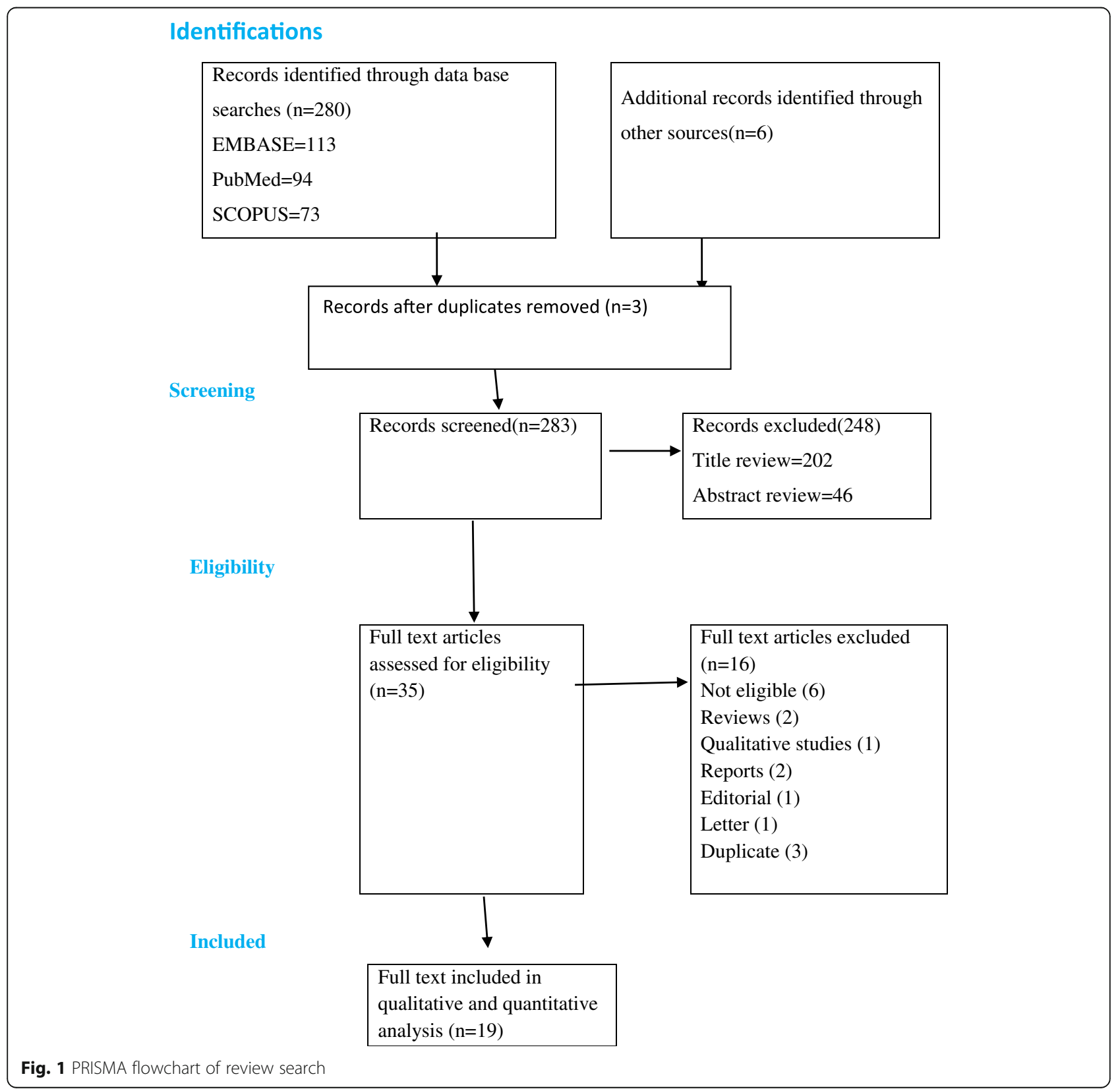




\section{Results}

\section{Identification of studies}

We identified 280 articles in our database search. Our manual search resulted additional six articles. Of these we excluded 205 articles during the review of duplicate and titles as they did not met the inclusion criteria (Fig. 1). In our review of abstracts and keywords we excluded another 46 studies and 19 articles with full-text that met the inclusion criteria were included in our final analysis.

\section{Characteristics of included studies}

Among the total of nineteen studies included in our analysis ten of them were done in Uganda $[5,7,8,10,11,20$, 26, 37-39], whereas five of the studies were conducted in Ethiopia [2, 3, 9, 16, 17] and the other studies were conducted in Kenya [18], Tanzania [15], Rwanda [14] and Sudan [40]. The publication year of those studies ranged from 2006 to 2017. All of the included studies used cross-sectional study design. One study used community

Table 1 Distribution of studies on depression in people living with HIV included in qualitative and quantitative analysis based on year, study design, sample size, instrument, country, response rate, study population and prevalence

\begin{tabular}{|c|c|c|c|c|c|c|c|c|}
\hline $\begin{array}{l}\text { Author (year) } \\
\text { (reference } \\
\text { number) }\end{array}$ & Study design(setting) & $\begin{array}{l}\text { Sample } \\
\text { size }\end{array}$ & Tool & $\begin{array}{l}\text { Response } \\
\text { rate }\end{array}$ & Country & Sampling & $\begin{array}{l}\text { Study } \\
\text { population }\end{array}$ & $\begin{array}{l}\text { Outcome } \\
\text { (magnitude of } \\
\text { depression) }\end{array}$ \\
\hline $\begin{array}{l}\text { Psaros C. } \\
\text { et. al. (2014) [37] }\end{array}$ & $\begin{array}{l}\text { Cross sectional study } \\
\text { (institution based) }\end{array}$ & 453 & HSC-D & $\begin{array}{l}\text { Not } \\
\text { reported }\end{array}$ & Uganda & $\begin{array}{l}\text { Used Cohort population } \\
\text { sample }\end{array}$ & adults & $38 \%(n=172)$ \\
\hline $\begin{array}{l}\text { Shumba C, } \\
\text { et. al. (2013) [11] }\end{array}$ & $\begin{array}{l}\text { Cross sectional study } \\
\text { (Community based } \\
\text { study) }\end{array}$ & 732 & Self report & $\begin{array}{l}\text { Not } \\
\text { reported }\end{array}$ & Uganda & $\begin{array}{l}\text { Random sampling } \\
\text { (specific technique not } \\
\text { reported) }\end{array}$ & $\begin{array}{l}\text { Adults on } \\
\text { HAART }\end{array}$ & $59 \%(n=429)$ \\
\hline $\begin{array}{l}\text { Kinyanda E. } \\
\text { et. al. (2017) [5] }\end{array}$ & $\begin{array}{l}\text { Cross sectional study } \\
\text { (institution based study) }\end{array}$ & 899 & DSM & $\begin{array}{l}\text { Not } \\
\text { reported }\end{array}$ & Uganda & Not reported & adults & $14 \%(n=126)$ \\
\hline $\begin{array}{l}\text { Yeneabat T. } \\
\text { et. al. (2017) [9] }\end{array}$ & $\begin{array}{l}\text { Cross sectional study } \\
\text { (institution) }\end{array}$ & 390 & CES-D & $\begin{array}{l}\text { Not } \\
\text { reported }\end{array}$ & Ethiopia & Not reported & adults & $76.7 \%(n=299)$ \\
\hline $\begin{array}{l}\text { Kinyanda E. } \\
\text { et. al. (2011) [38] }\end{array}$ & $\begin{array}{l}\text { Cross sectional study } \\
\text { (institution) }\end{array}$ & 618 & DSM-IV & $\begin{array}{l}\text { Not } \\
\text { reported }\end{array}$ & Uganda & Not reported & adults & $8.1 \%(n=50)$ \\
\hline $\begin{array}{l}\text { Nakasujja N. } \\
\text { et. al. (2010) [39] }\end{array}$ & $\begin{array}{l}\text { Cross sectional study } \\
\text { (institution setting) }\end{array}$ & 102 & CES-D & $\begin{array}{l}\text { Cohort } \\
\text { survey }\end{array}$ & Uganda & Not reported & Adults & $53.9 \%(n=55)$ \\
\hline $\begin{array}{l}\text { Akena D. } \\
\text { et. al. (2012) [26] }\end{array}$ & $\begin{array}{l}\text { Cross sectional study } \\
\text { (institution setting) }\end{array}$ & 368 & PHQ-9 & $\begin{array}{l}\text { Not } \\
\text { reported }\end{array}$ & Uganda & Simple random sampling & Adults & $17.4 \%(n=64)$ \\
\hline $\begin{array}{l}\text { Hatcher AM. } \\
\text { et. al. (2012) [7] }\end{array}$ & $\begin{array}{l}\text { Cross sectional study } \\
\text { (institution setting) }\end{array}$ & 270 & HSC-D & $\begin{array}{l}\text { Not } \\
\text { reported }\end{array}$ & Uganda & $\begin{array}{l}\text { Used Cohort population } \\
\text { sample }\end{array}$ & Adults & $23.7 \%(n=64)$ \\
\hline $\begin{array}{l}\text { Cohen MH. } \\
\text { et. al. (2009) [14] }\end{array}$ & $\begin{array}{l}\text { Cross sectional study } \\
\text { (institution setting) }\end{array}$ & 658 & CES-D & $\begin{array}{l}\text { Not } \\
\text { reported }\end{array}$ & Rwanda & $\begin{array}{l}\text { Used Cohort population } \\
\text { sample }\end{array}$ & Adults & $81 \%(n=533)$ \\
\hline $\begin{array}{l}\text { Musisi S. } \\
\text { et. al. (2014) [8] }\end{array}$ & $\begin{array}{l}\text { Cross sectional study } \\
\text { (institution setting) }\end{array}$ & 386 & PHQ-9 & $\begin{array}{l}\text { Not } \\
\text { reported }\end{array}$ & Uganda & $\begin{array}{l}\text { Used cohort population } \\
\text { sample }\end{array}$ & Adults & $30 \%(n=116)$ \\
\hline $\begin{array}{l}\text { Tesfaw G. } \\
\text { et. al. (2016) [2] }\end{array}$ & $\begin{array}{l}\text { Cross sectional study } \\
\text { (institution setting) }\end{array}$ & 417 & HADS & $100 \%$ & Ethiopia & $\begin{array}{l}\text { Systematic random } \\
\text { sampling }\end{array}$ & Adults & $41.2 \%(n=172)$ \\
\hline $\begin{array}{l}\text { Elbadawi A. } \\
\text { et. al. (2017) [40] }\end{array}$ & $\begin{array}{l}\text { Cross sectional study } \\
\text { (institution setting) }\end{array}$ & 362 & HADS & $\begin{array}{l}\text { Not } \\
\text { reported }\end{array}$ & Sudan & $\begin{array}{l}\text { Systematic random } \\
\text { sampling }\end{array}$ & Adults & $61.3 \%(n=222)$ \\
\hline $\begin{array}{l}\text { Eshetu DA. } \\
\text { et. al. (2014) [17] }\end{array}$ & $\begin{array}{l}\text { Cross sectional study } \\
\text { (institution setting) }\end{array}$ & 416 & PHQ-9 & $\begin{array}{l}\text { Not } \\
\text { reported }\end{array}$ & Ethiopia & $\begin{array}{l}\text { Systematic random } \\
\text { sampling }\end{array}$ & Adults & $38.94 \%(n=162)$ \\
\hline $\begin{array}{l}\text { Berhe H. } \\
\text { et. al. (2013) [3] }\end{array}$ & $\begin{array}{l}\text { Cross sectional study } \\
\text { (institution setting) }\end{array}$ & 269 & HAM-D & $\begin{array}{l}\text { Not } \\
\text { reported }\end{array}$ & Ethiopia & Not reported & adults & $43.9 \%(n=118)$ \\
\hline $\begin{array}{l}\text { Mohammed M. } \\
\text { et. al. (2015) [15] }\end{array}$ & $\begin{array}{l}\text { Cross sectional study } \\
\text { (institution setting) }\end{array}$ & 740 & PHQ-9 & $97 \%$ & Ethiopia & $\begin{array}{l}\text { Systematic random } \\
\text { sampling }\end{array}$ & Adults & $45.8 \%(n=339)$ \\
\hline $\begin{array}{l}\text { MB.ChB.PW } \\
(2011)[18]\end{array}$ & $\begin{array}{l}\text { Cross sectional study } \\
\text { (institution setting) }\end{array}$ & 400 & $\mathrm{BDI}$ & $\begin{array}{l}\text { Not } \\
\text { reported }\end{array}$ & Kenya & $\begin{array}{l}\text { Systematic random } \\
\text { sampling }\end{array}$ & & $47.25 \%(n=189)$ \\
\hline $\begin{array}{l}\text { Marwick KF. } \\
\text { et. al. (2010) [15] }\end{array}$ & $\begin{array}{l}\text { Cross sectional study } \\
\text { (institution setting) }\end{array}$ & 220 & ICD-10 & $97 \%$ & Tanzania & Convenience sampling & Adults & $2.7 \%(n=6)$ \\
\hline $\begin{array}{l}\text { Kahazura FM. } \\
\text { et. al. (2006) [20] }\end{array}$ & $\begin{array}{l}\text { Cross sectional study } \\
\text { (institution setting) }\end{array}$ & 1017 & CES-D & $\begin{array}{l}\text { Not } \\
\text { reported }\end{array}$ & Uganda & $\begin{array}{l}\text { Used Cohort population } \\
\text { sample }\end{array}$ & Adults & $47 \%(n=476)$ \\
\hline $\begin{array}{l}\text { Mpungu EN. } \\
\text { et. al, } 2011 \text { [10] }\end{array}$ & $\begin{array}{l}\text { Cross sectional study } \\
\text { (institution setting) }\end{array}$ & 500 & DSM (MINI) & $\begin{array}{l}\text { Not } \\
\text { reported }\end{array}$ & Ugnada & Not clearly indicated & adults & $46.4 \%(232)$ \\
\hline
\end{tabular}

Key: DSM Diagnostic and Statistical Manual of Mental Disorders, ICD International Classification of Disease, PHQ-9 Patient Health Questionnaire-9, CES-D Center for Epidemiologic Studies Depression Scale Revised, HAM-D Hamilton Depression Rating Scale, BDI Beck's Depression Inventory, HADS Hospital Anxiety and Depression Scale, HSC-D Hopkins Symptom Checklist for Depression 
samples [11] and eighteen studies used samples from institution [2, 3, 5, 7-10, 14-18, 20, 26, 37-40]. Regarding the instrument used, four studies used diagnostic instrument $[5,10,15,38]$, fourteen studies used screening instrument $[2,3,7-9,14,16,17,26,37,39,40]$ and one study used self-report questionnaire to assess depression in PLWHIV [11]. Majority(84.22\%) of the studies not reported response rate. Seven studies used random sampling technique, seven used the cohort sample, one study used covenant sampling and four studies not reported the sampling technique (See Table 1).

\section{Quality of included studies}

We used a modified version of the Newcastle-Ottawa scale (NOS) scale to evaluate the quality of included studies. The methodological quality was good for all nineteen studies. The risk of selection, measurement and non-response bias was low for all studies. The agreement between reviewers regarding the level of bias was moderate or almost perfect for all studies (Kappa statistic range 0.50-1 (Additional file 1: Table S1).

The results of pooled meta-analysis

Prevalence of depression in people living with HIV (PLWHIV)

Nineteen of the studies provided information regarding the prevalence of depression in PLWHIV in east Africa
[1-19] (Table 1). These nineteen studies could be combined to provide the pooled estimates. Based on the results of random-effects method, the pooled prevalence of depression in PLWHIV was 38.00\% (95\% CI 29.30-47.54) and the heterogeneity was considerable $\left(I^{2}=98.59 \%\right.$; $\mathrm{Q}=11276.10, \mathrm{df}=18$, variance $=0.08, p<0.0001$ ). The forest plots of the prevalence of depression in people living with HIV were shown in Fig. 2.

\section{Subgroup analyses of the prevalence of depression in people living with HIV (PLWHIV)}

Subgroup analysis were performed by type of instrument used to assess depression and the country where the studies were conducted as possible source of heterogeneity between the studies as well as to explore the prevalence in each country. For our subgroup analysis based on the country where the studies were conducted, we identified representative data only for Uganda and Ethiopia. For the rest of east African countries (Kenya, Tanzania, Rwanda and Sudan), there is limited data for subgroup analysis.

Of the included studies, ten reported the prevalence of depression in PLWHIV in Uganda [1-4, 6-9, 11, 19, 20]. The pooled prevalence estimates of depression in PLWHIV in Ugandawas30.88\% $(95 \%$ CI 20.84-43.13) (See Table 2).

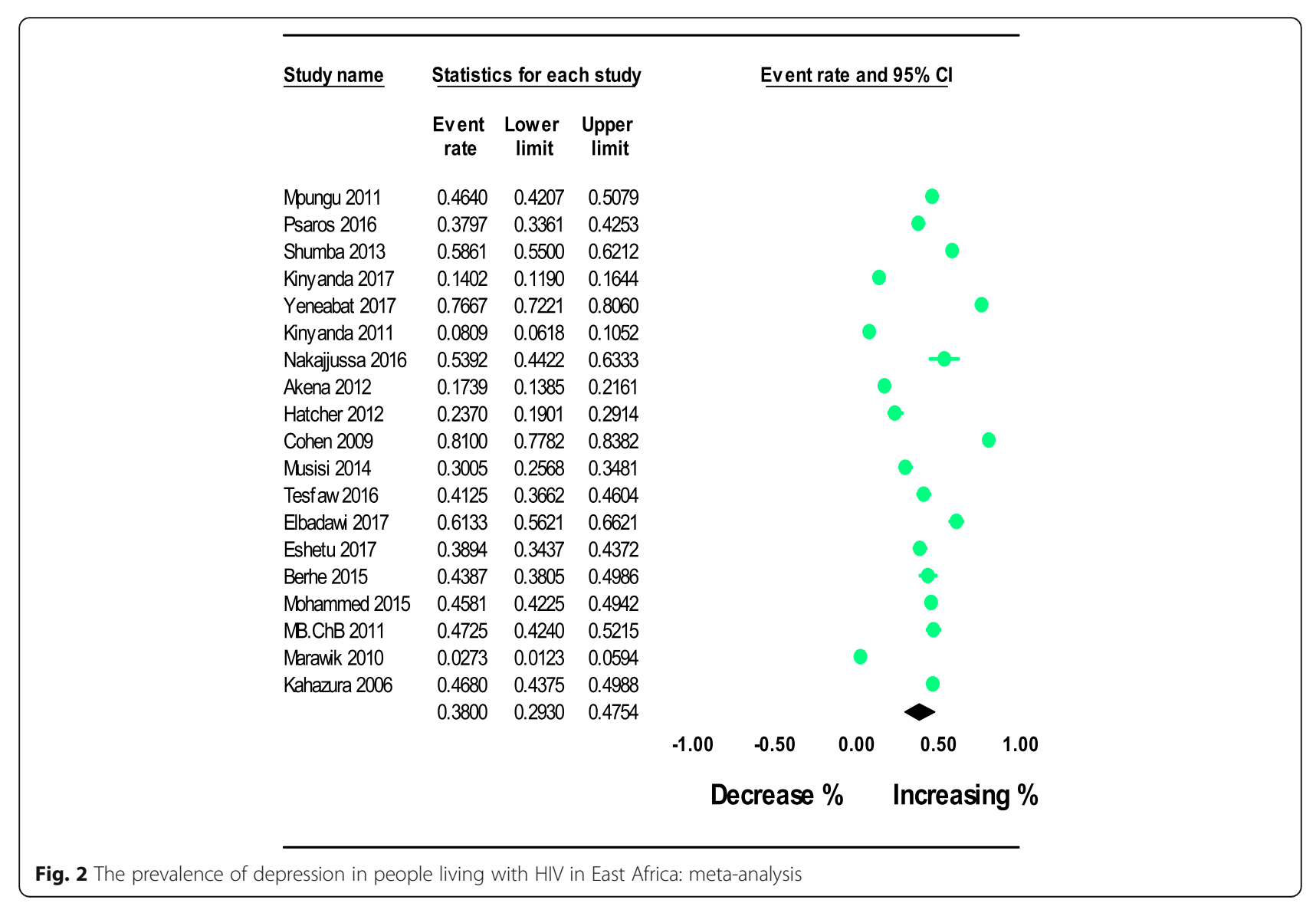


Table 2 Prevalence of depression in people with HIV in east Africa: Subgroup meta-analysis and heterogeneity analysis

\begin{tabular}{|c|c|c|c|c|c|c|c|}
\hline Characteristics & Observation (N) & Prevalence (\%) & $95 \% \mathrm{Cl}$ & 12 & Q & df & $P$ value \\
\hline \multicolumn{8}{|c|}{ Geographic location or country } \\
\hline Uganda & 10 & 30.88 & $20.84-43.13$ & $98.57 \%$ & 636.65 & 9 & $P<0.0001$ \\
\hline Ethiopia & 5 & 49.79 & $37.22-62.38$ & 97.08 & 136.79 & 4 & $P<0.0001$ \\
\hline \multicolumn{8}{|c|}{ Instrument used or tool used } \\
\hline Diagnostic & 4 & 12.40 & $4.0-32.80$ & $98.94 \%$ & 281.77 & 3 & $P<0.0001$ \\
\hline Screening & 14 & 46.00 & $36.90-55.38$ & $97.96 \%$ & 638.36 & 13 & $P<0.0001$ \\
\hline \multicolumn{8}{|l|}{ Study Setting } \\
\hline Institution based & 18 & 36.86 & $27.87-46.86$ & $98.59 \%$ & 1207.91 & 17 & $P<0.0001$ \\
\hline \multicolumn{8}{|l|}{ Sample size } \\
\hline$<400$ & 8 & 34.20 & $19.84-52.18$ & $98.32 \%$ & 416.89 & 7 & $P<0.0001$ \\
\hline$>400$ & 11 & 40.46 & $29.39-52.60$ & $98.84 \%$ & 858.66 & 10 & $P<0.0001$ \\
\hline \multicolumn{8}{|c|}{ Reference to diagnostic criteria } \\
\hline DSM/ICD & 4 & 12.40 & $4.0-32.80$ & $98.94 \%$ & 281.77 & 3 & $P<0.0001$ \\
\hline PHQ-9 & 4 & 32.15 & $21.58-44.92$ & $96.61 \%$ & 88.57 & & $P<0.0001$ \\
\hline HADS & 2 & 51.30 & $32.20-70.10$ & $96.75 \%$ & 30.82 & 1 & $P<0.0001$ \\
\hline CES-D & 4 & 66.14 & $44.34-82.73$ & $98.67 \%$ & 226.22 & 3 & $P<0.0001$ \\
\hline HSC-D & 2 & 30.50 & $18.50-46.10$ & $93.51 \%$ & 14.41 & 1 & $P<0.0001$ \\
\hline \multicolumn{8}{|l|}{ Year of publication } \\
\hline 2006-2010 & 3 & 33.90 & $10.17-69.93$ & $99.25 \%$ & 267.34 & 2 & $P<0.0001$ \\
\hline $2011-2013$ & 7 & 32.03 & $19.49-47.84$ & $98.52 \%$ & 406.32 & 6 & $P<0.0001$ \\
\hline 2014-2017 & 9 & 43.50 & $31.23-56.69$ & $98.37 \%$ & $98.37 \% 489.63$ & 8 & $P<0.0001$ \\
\hline
\end{tabular}

Five studies reported the prevalence of depression in PLWHIV in Ethiopia [5, 12, 14-16]. The pooled prevalence of depression in PLWHIV in Ethiopia was 49.79\% (95\% CI37.22-62.38). (See Table 2). In our analysis the prevalence of depression in PLWHIV in Ethiopia is significantly higher than the prevalent in Uganda $(P<.00001)$. For the rest of east African countries, there is limited data for subgroup analysis. We found only one study conducted in each of the other four east African countries such as Kenya [18], Tanzania [15], Rwanda [14] and Sudan [40].

We also performed subgroup analysis based on the instrument used to assess depression. Four studies used diagnostic instrument (DSM or ICD) and $[1,4$, $6,18,20]$ and fourteen studies used screening instrument (PHQ-9, HADS, BDI, CES-D, or HSC-D) to assess depression in people living with HIV in east Africa [1, 5, 7-17, 19]. The pooled prevalence of depression in people living with HIV was $12.40 \%$ (95\% CI $4.0-32.80$ ) and $46 \%$ (95\% CI 36.90-55.38) for the studies conducted using diagnostic and screening instrument respectively (see Table 2).

Furthermore, we conducted subgroup analysis based on each instrument used to assess depression. The pooled prevalence estimates of depression for the studies conducted using CES-D 66.14\% (44.34-82.73) and HADS
$51.30 \%$ (32.20-70.10) were significantly higher than results of studies conducted using DSM or ICD12.40\% (95\% CI 4.0-32.80), PHQ-9 32.15\% (21.58-44.92), and HSC-D $30.50 \%$ (18.50-46.10) (see Table 2).

Finally, we performed subgroup analysis based on the setting where the studies were conducted. The pooled prevalence of depression in people living with HIV in east Africa for institution based studies was 36.86\% (95\% CI 27.87-46.86) (see Table 2).

\section{Publication bias}

The funnel plot and Egger's regression tests $(B=-9.17$, $\mathrm{SE}=6.16, \mathrm{P}=0.155)$ provided no evidence of substantial publication bias for the prevalence of depression in PLWHIV in east Africa (Fig. 3).

\section{Sensitivity analysis}

For the purpose of further investigating potential source of heterogeneity in the analysis of the prevalence of depression in PLWHIV, we performed leave-one-out sensitivity analysis. Our sensitivity analysis showed that our findings were strong and not dependent on a single study. Our pooled estimated prevalence varied between 35.86(27.53-44.25) and 41.39(32.33-51.07) after deletion of a single study (see Table 3 ). 
Funnel Plot of Standard Error by Logit event rate

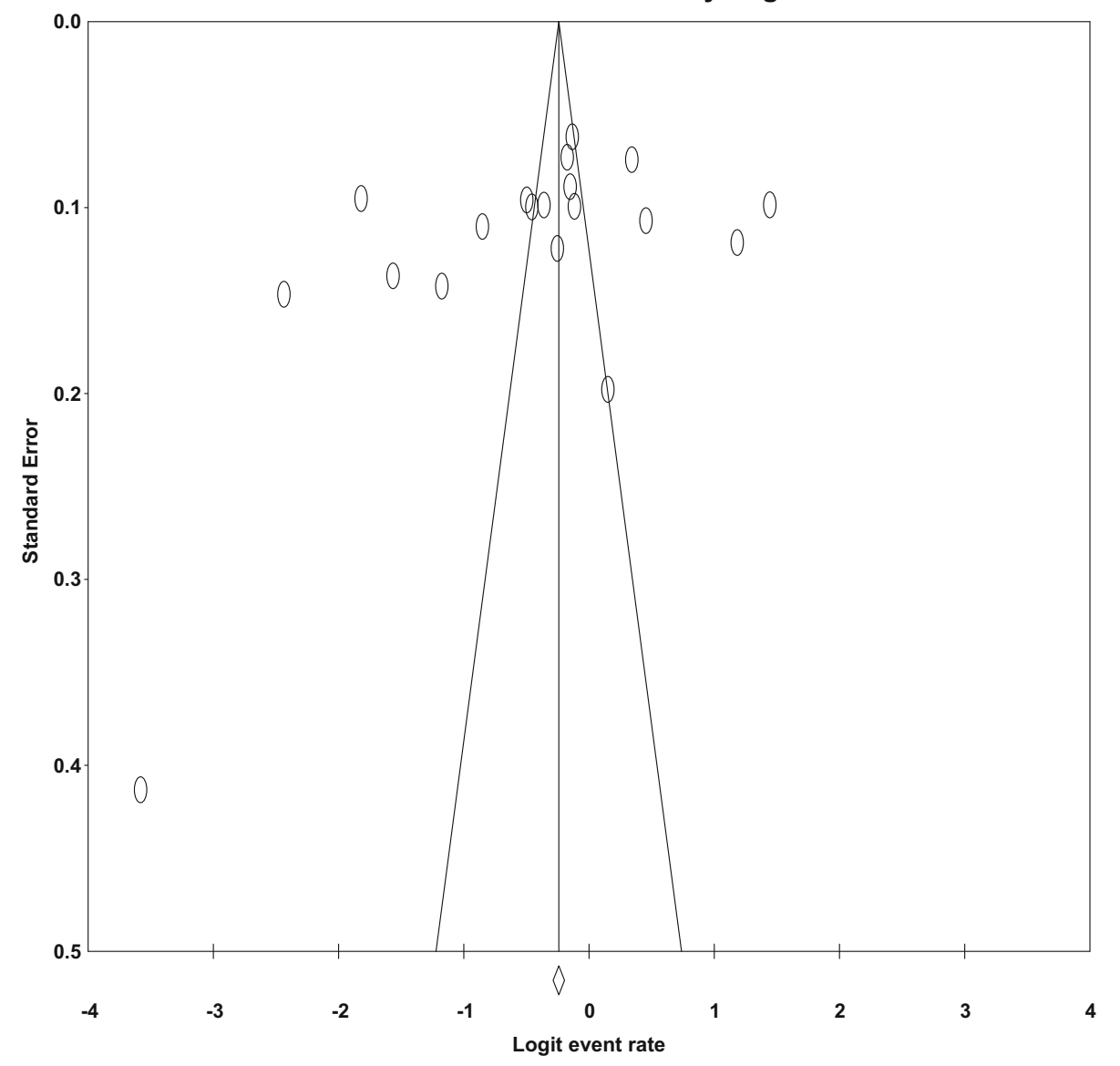

Fig 3 Funnel plot of risk of publication bias for the prevalence of depression in PLWHIV in east Africa

\section{Determinants of depression in people living with HIV}

Of 19 included studies, 11 studies that reported factors associated with depression in peoples living with HIV in east Africa were included in the qualitative analysis [2, 3 , 5, 7, 9, 10, 16, 17, 20, 26, 38] (See Table 4). Association between WHO clinical staging of disease and depression was observed in three studies $[2,10,17]$.

In the current review presence of opportunistic infection [9], perceived stigma [2, 20], negative life event [38], WHO clinical staging of disease [17], hospitalization in the past one month [17], stressful life events [38], food insecurity [9], mean self-efficacy (>80\%) [41], missed frequency of clinic visit one to three weeks [16], frequency of follow-up [16], older age (age 60-69) [17], income less than 200 Ethiopian birr [3, 17], urban residence [3] and government employee [3] were strongly and significantly associated with depression in people living with HIV in east Africa (See Table 4).

\section{Discussion}

To our knowledge, this is the first systematic review and meta-analysis of depression and determinants in
PLWHIV in east Africa. The main aim of the study was identification of epidemiological information on the overall prevalence and common determinants of depression in PLWHIV in the area. It is also believed that the results of this review provide greater precision than the results of the studies individually considered. Nineteen studies that analyzed the prevalence of depression and associated factors in PLWHIV in east Africa were included.

The pooled prevalence estimate of depression in this meta-analysis was found a to be $38 \%$ in PLWHIV. The magnitude of depression in PLWHIV differed by the setting and the country where the studies were conducted as well as the type of instrument used to measure depression. When measured by DSM or ICD the estimated pooled prevalence of major depressive disorder appeared to be $12.40 \%$, but the pooled prevalence of depression was $46 \%$ as measured by screening instruments. The magnitude of major depressive disorder in PLWHIV in our meta-analysis is much higher compared with the $4 \%$ found in the general population [42]. 
Table 3 Sensitivity analysis of prevalence for each study being removed at a time: prevalence and 95\% confidence interval of depression in people living with HIV in east Africa

\begin{tabular}{lll}
\hline Study excluded & Prevalence & $95 \% \mathrm{Cl}$ \\
\hline Mpungu 2011 & 37.49 & $28.32-47.66$ \\
Psaros 2016 & 37.96 & $28.79-48.08$ \\
Shumba 2013 & 36.86 & $27.87-46.86$ \\
Kinyanda 2017 & 39.90 & $31.51-48.94$ \\
Yeneabat 2017 & 35.86 & $27.53-45.14$ \\
Kinyanda 2011 & 40.67 & $32.13-49.82$ \\
Nakajjussa 2016 & 37.17 & $28.31-46.99$ \\
Akena 2012 & 39.44 & $30.52-49.11$ \\
Hatcher 2012 & 38.89 & $29.88-48.74$ \\
Cohen 2009 & 35.59 & $27.78-44.25$ \\
Musisi 2014 & 38.45 & $29.67-48.42$ \\
Tesfaw 2016 & 37.78 & $28.63-47.89$ \\
Elbadawi 2017 & 36.74 & $27.90-46.56$ \\
Eshetu 2017 & 37.91 & $28.76-48.01$ \\
Berhe 2015 & 37.65 & $28.60-47.65$ \\
Mohammed 2015 & 37.50 & $28.19-47.84$ \\
MB.ChB 2011 & 37.46 & $28.36-47.54$ \\
Marawik 2010 & 41.39 & $32.33-51.07$ \\
Kahazura 2006 & 37.43 & $27.98-47.95$ \\
\hline Key. The anlysis &
\end{tabular}

Key. The analysis is based on random effect model

Our estimated pooled prevalence of depression (38\%) was higher than the results of systematic review and meta-analysis studies in sub-Saharan Africa which reported the pooled prevalence estimates of depression was $19 \%$ in people living HIV with sub-Saharan Africa [22]. These difference might be due to the socioeconomic and cultural differences of the countries.

In our study the pooled prevalence estimates of depression in PLWHIV in Ethiopia (49.79\%) was significantly higher than the pooled prevalence estimates of depression in Uganda(30.88\%). The difference might be due to all studies done in Ethiopia used screening instrument to determine depression and based on the pooled prevalence estimate, the prevalence of depression measured by screening instrument $(46 \%)$ was higher than the prevalence of depression measured by diagnostic instrument (12.40\%).

As expected, the magnitude of depression showed a considerable variations depending on the measurement used to determine depression in PLWHIV. The pooled prevalence of depression in PLWHIV was apparently higher in studies conducted using screening instrument than diagnostic instrument. The estimated pooled prevalence of depression in PLWHIV was found to be $66.14 \%$ , $51.30 \%, 12.40 \%, 32.15 \%$ and $30.50 \%$ as measured by CES-D, HADS, DSM or ICD, PHQ-9, and HSC-D respectively. The fact that diagnostic instrument give more weights towards the high specificity as compared to screening instrument which gives more emphasis towards high sensitivity might be the main reason for the observed difference. The other possible explanation might be diagnostic instrument uses strict criteria as compared to screening instrument as screening instrument aimed to identify potential indicators for disease or potential disease rather than establishing the presence or absence of disease which is the main purpose of diagnostic instrument. Finally, the possible interpretation for the variation in magnitude of depression among the different screening instrument may be due to difference in the sensitivity and specificity the tools used to screen depression in PLWHIV. The findings support the view that validation and use of standard instrument for screening as well as diagnosis of depression in PLWHIV.

Moreover, in our subgroup analysis of prevalence in PLWHIV by study setting show the pooled prevalence of depression in PLWHIV for the studies conducted institution-based setting was $36.86 \%$. This results are lower than unpooled results of depression in community setting which reported magnitude of depression 59\%. (see Tables 1 and 2). The fact that the community based study included in this review used self report of depression and all institution based studies used standard diagnostic or screening instrument to assess depression might be the possible reason for the observed difference in magnitude of depression in clinical and community based settings. In addition, the community based study is only one study so the observed result might be highly biased as it is self-report. The study suggest replication of studies in community samples to strengthen our finding as well as understanding of the precise estimates of depression in PLWHIV.

Concerning associated factors, Our qualitative synthesis showed that factors such as having opportunistic infection, perceived stigma, negative life event, WHO clinical staging of disease, hospitalization in the past one month, stressful life events, food insecurity, self-efficacy, missed frequency of clinic visit, frequency of follow-up, older age, low income, urban residence and being government employee were strongly and significantly associated with depression in people living with HIV in east Africa.

\section{Difference between studies}

The variation between the studies included in our systematic review and meta-analysis led to high level of heterogeneity in our analysis. The possible contributing factors for the variance in prevalence rates of depression in PLWHIV in east Africa includes the instrument used to measure depression, the study setting and populations. We conducted leave-one-out sensitivity analysis for the purpose of further investigating potential source of heterogeneity in the analysis of the prevalence of depression in PLWHIV. Our 
Table 4 Characteristics of factors associated with depression in people living with HIV east Africa by their odds ratio, confidence interval strength of association, author and year

\begin{tabular}{lllll}
\hline Factors & Odds ratio & $95 \%$ Confidence & Strength of association Adjusted for & Author, year \\
& (AOR) & interval & A
\end{tabular}

Past history of mania $2.73 \quad 1.16-6.40 \quad$ Moderate, negative

Gender, age, educational status, income, social Mpungu, 2011 support, self-efficacy, cognitive impairment, current alcohol use, current alcohol use disorder, duration of ART, CD4 count, WHO clinical staging of HIV disease, tuberculosis

$\begin{array}{llll}\begin{array}{l}\text { Mean self efficacy } \\ \text { score }>89 \%\end{array} & 0.61 & 0.41-0.90 & \text { Strong, negative }\end{array}$
score $>89 \%$

WHO clinical staging $\quad 1.88$ of HIV disease

Tuberculosis 2.37

$1.20-4.66$

$0.92-0.98$

$1.20-1.26$

AIDS stigma

$0.20-0.91$

CD4 count

0.43

$1.40-5.98$

Not have enough

2.89

food security

Negative life event score 6-10

4.89

Negative life event

16.67

score 6-11+

Stress score index $>10 \quad 7.18$

Food insecurity

3.83

$1.58-9.32$

Presence of Ols

HIV stage three

Perceived stigma

3.60

$2.23-5.80$

Medication

1.61

adherence

Social support
Strong, negative

Strong, negative

Moderate, positive

Moderate, negative

Moderate, positive

Strong, positive

Strong, positive

Strong, positive

Strong, positive

Moderate, positive

Strong, positive

Moderate, positive

Moderate, positive
Gender, age, educational status, income, social Mpungu, 2011 support, mania, cognitive impairment, current alcohol use, current alcohol use disorder, duration of ART, CD4 count, WHO clinical staging of HIV disease, tuberculosis

Gender, age, educational status, income, social Mpungu, 2011 support, mania, self-efficacy, cognitive impairment, current alcohol use, current alcohol use disorder, duration of ART, CD4 count, mania, tuberculosis

Gender, age, educational status, income, social Mpungu, 2011 support, mania, self-efficacy, cognitive impairment, current alcohol use, current alcohol use disorder, duration of ART, CD4 count, mania, WHO clinical staging of HIV disease

AIDS stigma, CD4 counts, sex

Akena, 2012

Age, CD4 counts, sex

Akena, 2012

Age, AIDS stigma, sex

Distance from HIV clinic, When knew HIV status, On ART, social support, negative life events, stress score index

Distance from HIV clinic, When knew HIV status, On ART, social support, food security, stress score index

Distance from HIV clinic, When knew HIV status, On ART, social support, food security, stress score index

Distance from HIV clinic, When knew HIV status, On ART, social support, food security, negative life event

Sex, age educational status, marital status, occupation, residence, number of dependent children, access to food aids, practice of agriculture, ownership of livestock, CD4 level, Ols

Akena, 2012

Kinyanda. 2011

Kinyanda. 2011

Kinyanda. 2011

Sex, age educational status, marital status, occupation, residence, number of dependent children, access to food aids, practice of agriculture, ownership of livestock, CD4 level, food insecurity

Age, educational status, marital status, residence, CD4 level, perceived stigma, medication adherence, social support

Age, educational status, marital status, residence, CD4 level, HIV stage, medication adherence, socia; support

Age, educational status, marital status, residence, CD4 level, HIV stage, social support

Age, educational status, marital status, residence, CD4 level, HIV stage, medication adherence
Kinyanda. 2011

Yeneabat, 2017

Yeneabat, 2017

Tesfaw, 2016

Tesfaw, 2016

Tesfaw, 2016

Tesfaw, 2016 
Table 4 Characteristics of factors associated with depression in people living with HIV east Africa by their odds ratio, confidence interval strength of association, author and year (Continued)

\begin{tabular}{|c|c|c|c|c|c|}
\hline Factors & $\begin{array}{l}\text { Odds ratio } \\
\text { (AOR) }\end{array}$ & $\begin{array}{l}95 \% \text { Confidence } \\
\text { interval }\end{array}$ & Strength of association & Adjusted for & Author, year \\
\hline Married & 0.01 & $0.01-0.07$ & Weak, positive & $\begin{array}{l}\text { Sexual relationship power scale, age, } \\
\text { educational status, heavy drinking, tobacco } \\
\text { use, WHO HIV stage, CD4 count, previously } \\
\text { treated with ART }\end{array}$ & Hatcher, 2012 \\
\hline Resilience score & 1.28 & $1.12-1.45$ & Weak, positive & $\begin{array}{l}\text { Study site, age, sex, stigma score, childhood } \\
\text { trauma score, negative coping score, negative } \\
\text { life event experience }\end{array}$ & Kinyanda, 2017 \\
\hline Stigma score & 1.37 & $1.08-1.73$ & Weak, positive & $\begin{array}{l}\text { Study site, age, sex, resilience childhood } \\
\text { trauma score, negative coping score, negative } \\
\text { life event experience }\end{array}$ & Kinyanda, 2017 \\
\hline $\begin{array}{l}\text { Childhood trauma } \\
\text { score }\end{array}$ & 1.25 & $1.02-1.55$ & Weak, positive & $\begin{array}{l}\text { Study site, age, sex, resilience stigma score, } \\
\text { negative coping score, negative life event } \\
\text { experience }\end{array}$ & Kinyanda, 2017 \\
\hline $\begin{array}{l}\text { Negative scoping } \\
\text { score }\end{array}$ & 1.50 & $1.17-1.92$ & Moderate, positive & $\begin{array}{l}\text { Study site, age, sex, resilience stigma score, } \\
\text { childhood trauma, negative life event } \\
\text { experience }\end{array}$ & Kinyanda, 2017 \\
\hline $\begin{array}{l}\text { Negative life } \\
\text { experience score }\end{array}$ & 1.81 & $1.46-2.25$ & Moderate, positive & $\begin{array}{l}\text { Study site, age, sex, resilience stigma score, } \\
\text { childhood trauma, negative scoring score }\end{array}$ & Kinyanda, 2017 \\
\hline Male sex & 1.633 & $1.138-2.342$ & Moderate, positive & $\begin{array}{l}\text { Marital status,income, verbal stigma, missed } \\
\text { frequency of clinic visit, frequency of clinic } \\
\text { visit/month }\end{array}$ & $\begin{array}{l}\text { Mohammed, } \\
2016\end{array}$ \\
\hline $\begin{array}{l}\text { Monthly } \\
\text { income<500eth.birr }\end{array}$ & 1.924 & $1.159,3.195$ & Moderate, positive & $\begin{array}{l}\text { Marital status, sex, verbal stigma, missed } \\
\text { frequency of clinic visit, frequency of clinic } \\
\text { visit/month }\end{array}$ & $\begin{array}{l}\text { Mohammed, } \\
2016\end{array}$ \\
\hline Had verbal stigma & 2.705 & $1.445,5.063$ & Moderate, positive & $\begin{array}{l}\text { Marital status, sex, verbal stigma, missed } \\
\text { frequency of clinic visit, frequency of clinic } \\
\text { visit/month }\end{array}$ & $\begin{array}{l}\text { Mohammed, } \\
2016\end{array}$ \\
\hline $\begin{array}{l}\text { Missed frequency of } \\
\text { clinic visit past } \\
\text { one,two and three } \\
\text { weeks }\end{array}$ & $\begin{array}{l}4.354 .56 \\
\text { and } 3.75 \\
\text { respectively }\end{array}$ & $\begin{array}{l}2.20-8.59,2.42-8.58 \\
\text { and } 1.39-9.93 \\
\text { respectively }\end{array}$ & Strong, positive & $\begin{array}{l}\text { Marital status, sex }{ }_{\text {"v }} \text { verbal stigma, frequency of } \\
\text { clinic visit/month }\end{array}$ & $\begin{array}{l}\text { Mohammed, } \\
2016\end{array}$ \\
\hline $\begin{array}{l}\text { Once, twice and three } \\
\text { times frequency of } \\
\text { clinic visit/month }\end{array}$ & $\begin{array}{l}19.033 \\
13.784 \text { and } \\
22.729\end{array}$ & $\begin{array}{l}2.095-172.878,1.430- \\
132.871 \text {, and } 2.450- \\
210.873 \text { respectively }\end{array}$ & Strong, positive & $\begin{array}{l}\text { Marital status, sex, verbal stigma, verbal } \\
\text { stigma, missed frequency of clinic visit }\end{array}$ & $\begin{array}{l}\text { Mohammed, } \\
2016\end{array}$ \\
\hline Female sex & 2.071 & $1.077-3.985$ & Moderate, positive & $\begin{array}{l}\text { Age, income, HIV stage, hospitalization in past } \\
\text { one month, felt stigmatized }\end{array}$ & Eshetu 2015 \\
\hline Age 30-39 & 2.761 & $1.165-6.540$ & Moderate, positive & $\begin{array}{l}\text { Sex, Income, HIV stage, hospitalization in past } \\
\text { one month, felt stigmatized }\end{array}$ & Eshetu 2015 \\
\hline Age 50-59 & 2.596 & $1.49-9.94$ & Moderate, positive & $\begin{array}{l}\text { Sex, Income, HIV stage, hospitalization in past } \\
\text { one month, felt stigmatized }\end{array}$ & Eshetu 2015 \\
\hline Age 60-69 & 19.645 & $4.02-95.99$ & Strong, positive & $\begin{array}{l}\text { Sex, Income, HIV stage, hospitalization in past } \\
\text { one month, felt stigmatized }\end{array}$ & Eshetu 2015 \\
\hline Income $<200$ Birr & 3.917 & $1.559,9.845$ & Strong, positive & $\begin{array}{l}\text { Age,Sex, HIV stage, hospitalization in past one } \\
\text { month, felt stigmatized }\end{array}$ & Eshetu 2015 \\
\hline Income201-400 Birr & 2.796 & $1.139-6.865$ & Moderate, positive & $\begin{array}{l}\text { Age, Sex, HIV stage, hospitalization in past one } \\
\text { month, felt stigmatized }\end{array}$ & Eshetu 2015 \\
\hline Income 401-700 Birr & 2.590 & $1.058-6.340$ & Moderate, positive & $\begin{array}{l}\text { Age, Sex, HIV stage, hospitalization in past one } \\
\text { month, felt stigmatized }\end{array}$ & Eshetu 2015 \\
\hline HIVStage III & 2.317 & $1.108-4.85$ & Moderate, positive & $\begin{array}{l}\text { Age, Sex, income hospitalization in past one } \\
\text { month, felt stigmatized }\end{array}$ & Eshetu 2015 \\
\hline HIV Stage IV & 8.769 & $1.93-39.87$ & Strong, positive & $\begin{array}{l}\text { Age, Sex, income hospitalization in past one } \\
\text { month, felt stigmatized }\end{array}$ & Eshetu 2015 \\
\hline $\begin{array}{l}\text { Hospitalized in the } \\
\text { past one Month }\end{array}$ & 15.26 & $1.463-159.22$ & Strong, positive & $\begin{array}{l}\text { Age, Sex, income month, felt stigmatized, } \\
\text { HIVStage }\end{array}$ & Eshetu 2015 \\
\hline
\end{tabular}


Table 4 Characteristics of factors associated with depression in people living with HIV east Africa by their odds ratio, confidence interval strength of association, author and year (Continued)

\begin{tabular}{|c|c|c|c|c|c|}
\hline Factors & $\begin{array}{l}\text { Odds ratio } \\
\text { (AOR) }\end{array}$ & $\begin{array}{l}95 \% \text { Confidence } \\
\text { interval }\end{array}$ & Strength of association & Adjusted for & Author, year \\
\hline Felt stigmatized & 3.597 & $1.86-6.95$ & Strong, positive & $\begin{array}{l}\text { Age, Sex, income month, HIVStage, } \\
\text { hospitalized in the past one Month }\end{array}$ & Eshetu 2015 \\
\hline Age $>50$ years & 1.93 & $1.09-3.42$ & Moderate, positive & $\begin{array}{l}\text { Religion, education, marital status, sex, source } \\
\text { of income, CD4 level, HIVStage, number of } \\
\text { living children }\end{array}$ & Kaharuza, 2006 \\
\hline $\begin{array}{l}\text { Pensions as source of } \\
\text { income }\end{array}$ & 1.81 & $1.24-2.66$ & Moderate, positive & $\begin{array}{l}\text { Religion, education, marital status, sex, CD4 } \\
\text { level, HIVStage, number of living children, age }\end{array}$ & Kaharuza, 2006 \\
\hline Primary education & 1.69 & $1.12-2.52$ & Moderate, positive & $\begin{array}{l}\text { Religion, marital status, sex, CD4 level, } \\
\text { HIVStage, number of living children, age, } \\
\text { source of income }\end{array}$ & Kaharuza, 2006 \\
\hline CD4 count 50-99 & 2.02 & $1.22-3.36$ & Moderate, positive & $\begin{array}{l}\text { Religion, marital status, sex, education, } \\
\text { HIVStage, number of living children, age, } \\
\text { source of income }\end{array}$ & Kaharuza, 2006 \\
\hline CD4 count $<50$ & 2.34 & 1.39-3.93 & Moderate, positive & $\begin{array}{l}\text { Religion, education, marital status, sex, } \\
\text { HIVStage, number of living children, age, } \\
\text { source of income }\end{array}$ & Kaharuza, 2006 \\
\hline Urban residence & 3.19 & $1.50-6.65$ & Strong, positive & $\begin{array}{l}\text { Sex, marital status, income, educational status, } \\
\text { occupation, CD4 level }\end{array}$ & Berhe, 2013 \\
\hline Income $<200$ ETB & 4.43 & $1.35-14.58$ & Strong, positive & $\begin{array}{l}\text { Sex, residence, marital status, educational } \\
\text { status, occupation, CD4 level }\end{array}$ & Berhe, 2013 \\
\hline Unemployed & 2.74 & $1.34-5.57$ & Moderate, positive & $\begin{array}{l}\text { Sex, residence, marital status, educational } \\
\text { status, CD4 level }\end{array}$ & Berhe, 2013 \\
\hline $\begin{array}{l}\text { Government } \\
\text { employee }\end{array}$ & 3.56 & $1.73-7.30$ & Strong, positive & $\begin{array}{l}\text { Sex, residence, marital status, educational } \\
\text { status, CD4 level }\end{array}$ & Berhe, 2013 \\
\hline
\end{tabular}

sensitivity analysis showed that our findings were strong and not dependent on a single study.

\section{Strength and limitations}

The strength of the study includes the use of predefined search strategy in order to reduce reviewers bias as well as performing data extraction and quality assessment by two independent reviewers to minimize the possible reviewer bias. The other strength is performing sensitivity and subgroup analysis based on study setting, instrument used, and country of study to identify the small study effect and the risk of heterogeneity. Finally, evaluating the quality of the studies included in analysis and based on the results from the assessment of the study quality the methodological quality was generally good. Nevertheless, the study has some limitations: first, small number of studies were included in our subgroup analysis which reduce the precision of the estimate; second, apparent heterogeneity was identified among the studies; due to inconsistent adjustment and inclusion of factors determining depression in PLWHIV we done only qualitative analysis for associated factors of depression.

\section{Conclusion}

Our study found that the pooled prevalence estimate of depression in PLWHIV was 38\% (95\% CI 29.30-47.54). In our study the pooled prevalence estimates of depression in PLWHIV in Ethiopia was significantly higher than the pooled prevalence estimates of depression in Uganda. In addition the prevalence of depression was significantly higher in studies conducted by using screening as compared to diagnostic instrument. The study also resulted in a significant variation in prevalence of depression based on the instrument used. These findings have several implications for clinical practice and research. Based on this finding routine screening and integrated management of mental health condition into the existing HIV care services is warranted in east Africa. Validation and use of standard instrument to assess depression in PLWHIV is needed. In addition longitudinal and community based studies focusing on incidence and determinates of depression in PLWHIV are recommended. Attention need to be given for those people who have opportunistic infection, older age, advanced HIV stage, experienced stressful life events,who have perceived stigma and those who are on ART to prevent risk of non-adherence and treatment resistance and further to improve the quality PLWHIV.

\section{Additional files}

Additional file 1: Table S1. Summary of agreed level of bias and leve of agreement on the methodological qualities of included studies in meta-analysis based on sampling, outcome, response rate and method of analysis. (DOCX $15 \mathrm{~kb}$ ) 


\section{Abbreviations}

BDI: Beck's Depression Inventory; CES-D: Center for Epidemiologic Studies Depression Scale Revised; DSM: Diagnostic and Statistical Manual of Mental Disorders; HADS: Hospital Anxiety and Depression Scale; HAM-D: Hamilton Depression Rating Scale; HIV: Human Immunodeficiency Virus; HSCD: Hopkins Symptom Checklist for Depression; ICD: International Classification of Disease; PHQ-9: Patient Health Questionnaire-9. PLWHIV: people living with Human Immunodeficiency Virus

\section{Availability of data and materials}

All data generated or analyzed during this study are included in this article.

\section{Authors' contributions}

The author (GA) performed the search, data extraction, analyses and draft and approval of final manuscript. MA performed data extraction, quality assessment and approved final manuscript. MS participated in discussion and consensus and approved the final manuscript.

\section{Ethics approval and consent to participate}

N/A.

\section{Consent for publication}

N/A

\section{Competing interests}

The authors declare that they have no competing interests.

\section{Publisher's Note}

Springer Nature remains neutral with regard to jurisdictional claims in published maps and institutional affiliations.

\section{Author details}

${ }^{1}$ Research and Training Department, Amanuel Mental Specialized Hospital, Addis Ababa, Ethiopia. ²Department of Psychiatry, Paulo's millennium medical college, Addis Ababa, Ethiopia.

\section{Received: 15 January 2018 Accepted: 6 August 2018} Published online: 15 August 2018

\section{References}

1. Feuillet P, Lert F, Tron L, Aubriere C, Spire B, Dray-Spira R. Prevalence of and factors associated with depression among people living with HIV in France. Hiv Medicine. 2017;18(6):383-94.

2. Tesfaw G, Ayano G, Awoke T, Assefa D, Birhanu Z, Miheretie G, et al. Prevalence and correlates of depression and anxiety among patients with HIV on-follow up at Alert Hospital, Addis Ababa. Ethiopia. BMC psychiatry. 2016;16(1):368

3. Berhe H, Bayray A. Prevalence of depression and associated factors among people living with HIV/AIDS in tigray, North Ethiopia: A cross sectional hospital based study. International Journal of Pharmaceutical Sciences and Research. 2013;4(2):761-71.

4. Kinyanda E, Kuteesa M, Scholten F, Mugisha J, Baisley K, Seeley J. Risk of major depressive disorder among older persons living in HIV-endemic central and southwestern Uganda. AIDS care. 2016;28(12):1516-21.

5. Kinyanda E, Nakasuija N, Levin J, Birabwa $H$, Mpango $R$, Grosskurth $H$, et al. Major depressive disorder and suicidality in early HIV infection and its association with risk factors and negative outcomes as seen in semi-urban and rural Uganda. Journal of affective disorders. 2017;212:117-27.

6. Peterson K, Togun T, Klis S, Menten J, Colebunders R. Depression and posttraumatic stress disorder among HIV-infected Gambians on antiretroviral therapy. AIDS Patient Care STDs. 2012;26(10):589-96.

7. Hatcher AM, Tsai AC, Kumbakumba E, Dworkin SL, Hunt PW, Martin JN, et al. Sexual relationship power and depression among HIV-infected women in Rural Uganda. PloS one. 2012;7(12):e49821.

8. Musisi S, Wagner GJ, Ghosh-Dastidar B, Nakasujja N, Dickens A, Okello E. Depression and sexual risk behaviour among clients about to start HIV antiretroviral therapy in Uganda. International journal of STD \& AIDS. 2014;25(2):130-7.

9. Yeneabat T, Bedaso A, Amare T. Factors associated with depressive symptoms in people living with HIV attending antiretroviral clinic at Fitche Zonal Hospital, Central Ethiopia: Cross-sectional study conducted in 2012. Neuropsychiatric Disease and Treatment. 2017;13:2125-31.
10. Nanni MG, Caruso R, Mitchell AJ, Meggiolaro E, Grassi L. Depression in HIV infected patients: a review. Curr Psychiatry Rep. 2015:17(1):530.

11. Shumba C, Atukunda R, Imakit R, Memiah P. Prevalence of depressive symptoms amongst highly active antiretroviral therapy (HAART) patients in AIDSrelief Uganda. Journal of Public Health in Africa. 2013;4(2):84-7.

12. Niu L, Luo D, Liu Y, Silenzio VMB, Xiao S. The Mental Health of People Living with HIV in China, 1998-2014: A Systematic Review. PLOS ONE. 2016;11(4):e0153489.

13. Wang T, Fu H, Kaminga AC, Li Z, Guo G, Chen L, et al. Prevalence of depression or depressive symptoms among people living with HIV/AIDS in China: a systematic review and meta-analysis. BMC Psychiatry. 2018;18(1):160.

14. Cohen MH, Fabri M, Cai X, Shi Q, Hoover DR, Binagwaho A, et al. Prevalence and predictors of posttraumatic stress disorder and depression in HIVinfected and at-risk Rwandan women. Journal of women's health (2002). 2009;18(11):1783-91.

15. Marwick KF, Kaaya SF. Prevalence of depression and anxiety disorders in HIVpositive outpatients in rural Tanzania. AIDS care. 2010;22(4):415-9.

16. Mohammed M, Mengistie B, Dessie Y, Godana W. Prevalence of depression and associated factors among HIV patients seeking treatments in ART clinics at Harar Town. Eastern Ethiopia. J AIDS Clin Res. 2015;6(474):2.

17. Eshetu DA, Meseret S, Kebede MA, Techane GN, Gizachew KD, Tegegne MT, et al. Prevalence of depression and associated factors among HIV/AIDS Patients attending ART Clinic at Debrebirhan referral hospital, North Showa, Amhara Region, Ethiopia. Clin Psychiatry. 2015;1(1):1-7.

18. Ng'ang'a PW. Mathai M. and Obondo A. Prevalence of anxiety and depression among hiv/aids patients attending the comprehensive care centre (ccc), Kenyatta national hospital (knh). Grey literature. 2011.

19. Belete A, Andaregie G, Tareke M, Birhan T, Azale T. Prevalence of anxiety and associated factors among people living HIV/AIDS at debretabor general hospital anti retro viral clinic Debretabor, Amhara, Ethiopia, 2014. American Journal of Psychiatry and Neuroscience. 2014;2(6):109-14.

20. Kaharuza FM, Bunnell R, Moss S, Purcell DW, Bikaako-Kajura W, Wamai N, et al. Depression and CD4 cell count among persons with HIV infection in Uganda. AIDS and behavior. 2006;10(4 Suppl):S105-11.

21. Global, regional, and national incidence, prevalence, and years lived with disability for 310 diseases and injuries, 1990-2015: a systematic analysis for the Global Burden of Disease Study 2015. Lancet. 2016; 388(10053):1545-602.

22. Bernard C, Dabis F, de Rekeneire N. Prevalence and factors associated with depression in people living with HIV in sub-Saharan Africa: A systematic review and meta-analysis. PloS one. 2017;12(8):e0181960.

23. Adewuya AO, Afolabi MO, Ola BA, Ogundele OA, Ajibare AO, Oladipo BF, et al. Relationship between depression and quality of life in persons with HIV infection in Nigeria. The International Journal of Psychiatry in Medicine. 2008;38(1):43-51.

24. Nakimuli-Mpungu E, Musisi S, Katabira E, Nachega J, Bass J. Prevalence and factors associated with depressive disorders in an HIV+ rural patient population in southern Uganda. Journal of affective disorders. 2011;135(1):160-7

25. Olley BO, Seedat S, Stein DJ. Persistence of psychiatric disorders in a cohort of HIV/AIDS patients in South Africa: a 6-month follow-up study. Journal of psychosomatic research. 2006:61(4):479-84.

26. Akena D, Musisi S, Joska J, Stein DJ. The association between aids related stigma and major depressive disorder among HIV-positive individuals in Uganda. PloS one. 2012;7(11):e48671.

27. Olley B, Seedat S, Nei D, Stein D. Predictors of major depression in recently diagnosed patients with HIV/AIDS in South Africa. AIDS patient care and STDs. 2004;18(8):481-7.

28. Sin NL, DiMatteo MR. Depression treatment enhances adherence to antiretroviral therapy: a meta-analysis. Annals of Behavioral Medicine. 2014 47(3):259-69.

29. Gonzalez JS, Batchelder AW, Psaros C, Safren SA. Depression and HIV/AIDS treatment nonadherence: a review and meta-analysis. Journal of acquired immune deficiency syndromes (1999). 2011;58(2):181-7.

30. Hartzell JD, Janke IE, Weintrob AC. Impact of depression on HIV outcomes in the HAART era. Journal of Antimicrobial Chemotherapy. 2008;62(2):246-55.

31. Asangbeh SL, Sobngwi JL, Ekali GL, Eyoum C, Msellati P. Predictors of depression among patients on art in a rural health district in North West Cameroon. AIDS care. 2016:28(2):205-8.

32. Reviews UoYCf, Dissemination. Systematic reviews: CRD's guidance for undertaking reviews in health care. University of York: Centre for Reviews \& Dissemination; 2009 
33. Stang A. Critical evaluation of the Newcastle-Ottawa scale for the assessment of the quality of nonrandomized studies in meta-analyses. European journal of epidemiology. 2010;25(9):603-5.

34. Landis JR, Koch GG. The measurement of observer agreement for categorical data. Biometrics. 1977;33:159-74.

35. Borenstein M, Hedges LV, Higgins J, Rothstein HR. A basic introduction to fixed-effect and random-effects models for meta-analysis. Research synthesis methods. 2010;1(2):97-111

36. Higgins JP, Thompson SG, Deeks JJ, Altman DG. Measuring inconsistency in meta-analyses. BMJ: British Medical Journal. 2003;327(7414):557.

37. Psaros C, Haberer JE, Boum Y II, Tsai AC, Martin JN, Hunt PW, et al. The Factor Structure and Presentation of Depression Among HIV-Positive Adults in Uganda. AIDS and behavior. 2014;19(1):27-33.

38. Kinyanda E, Hoskins S, Nakku J, Nawaz S, Patel V. Prevalence and risk factors of major depressive disorder in HIV/AIDS as seen in semi-urban Entebbe district. Uganda. BMC psychiatry. 2011;11:205.

39. Nakasuija N, Skolasky RL, Musisi S, Allebeck P, Robertson K, Ronald A, et al. Depression symptoms and cognitive function among individuals with advanced HIV infection initiating HAART in Uganda. BMC psychiatry. 2010;10:44.

40. Elbadawi A, Mirghani H. Depression among HIV/AIDS Sudanese patients: a cross-sectional analytic study. The Pan African medical journal. 2017;26:43.

41. Nakimuli-Mpungu E, Mojtabai R, Alexandre PK, Musisi S, Katabira E, Nachega $J B$, et al. Lifetime depressive disorders and adherence to anti-retroviral therapy in HIV-infected Ugandan adults: A case-control study. Journal of affective disorders. 2013;145(2):221-6.

42. Waraich P, Goldner EM, Somers JM, Hsu L. Prevalence and incidence studies of mood disorders: a systematic review of the literature. Canadian journal of psychiatry Revue canadienne de psychiatrie. 2004;49(2):124-38.

Ready to submit your research? Choose BMC and benefit from:

- fast, convenient online submission

- thorough peer review by experienced researchers in your field

- rapid publication on acceptance

- support for research data, including large and complex data types

- gold Open Access which fosters wider collaboration and increased citations

- maximum visibility for your research: over $100 \mathrm{M}$ website views per year

At $\mathrm{BMC}$, research is always in progress.

Learn more biomedcentral.com/submissions 